\title{
Culture of patient safety in hospital units of gynecology and obstetrics: a cross-sectional study
}

\author{
Cultura de segurança do paciente em unidades hospitalares de ginecologia e obstetrícia: estudo transversal \\ Cultura de seguridad del paciente en unidades hospitalarias de ginecología y obstetricia: estudio transversal
}

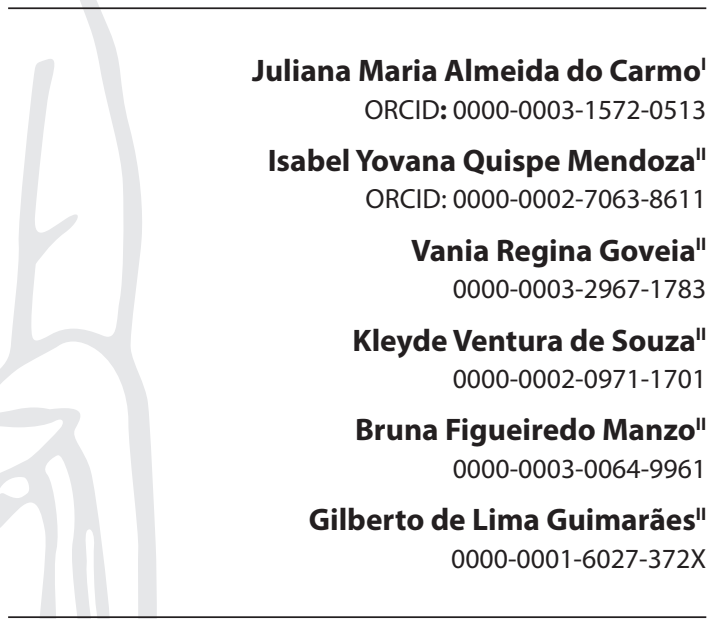

'Universidade Federal de Minas Gerais, Hospital das Clínicas. Belo Horizonte, Minas Gerais, Brazil. "Universidade Federal de Minas Gerais. Belo Horizonte, Minas Gerais, Brazil.

How to cite this article: Carmo JMA, Mendoza IYQ, Goveia VR, Souza KV, Manzo BF, Guimarães GL. Culture of patient safety in hospital units of gynecology and obstetrics: a cross-sectional study.

Rev Bras Enferm. 2020;73(5):e20190576. doi: http://dx.doi.org/10.1590/0034-7167-2019-0576

Corresponding author:

Isabel Yovana Quispe Mendoza

E-mail: isabelyovana@gmail.com



EDITOR IN CHIEF: Antonio José de Almeida Filho ASSOCIATE EDITOR: Hugo Fernandes

Submission: 08-01-2019

Approval: $03-20-2020$

\begin{abstract}
Objectives: to assess the patient safety culture of the health team working in three maternity hospitals. Methods: observational, cross-sectional, comparative study. 301 professionals participated in the study. The Hospital Survey on Patient Safety Culture questionnaire validated in Brazil was used. For data analysis, it was considered a strong area in the patient safety culture when positive responses reached over $75 \%$; and areas that need improvement when positive responses have reached less than $50 \%$. To compare the results, standard deviation and thumb rule were used. Results: of the 12 dimensions of patient safety culture, none obtained a score above $75 \%$, with nine dimensions scoring between 19\% and $43 \%$ and three dimensions between $55 \%$ and $57 \%$. Conclusions: no strong dimensions for safety culture were identified in the three maternity hospitals. It is believed that these results may contribute to the development of policies that promote a culture of safety in institutions. Descriptors: Patient Safety; Organizational Culture; Hospital Gynecology and Obstetrics Unit; Cross-Sectional Studies; Patient Care Team.
\end{abstract}

\section{RESUMO}

Objetivos: avaliar a cultura de segurança do paciente da equipe de saúde que atua em três maternidades. Métodos: estudo observacional, transversal, comparativo. Participaram do estudo 301 profissionais. Utilizou-se o questionário Hospital Survey on Patient Safety Culture validado no Brasil. Para a análise dos dados, considerou-se área forte na cultura de segurança do paciente quando as respostas positivas atingiram acima de $75 \%$; e áreas que precisam de melhorias quando as respostas positivas atingiram menos de $50 \%$. Para a comparação dos resultados, empregou-se desvio-padrão e regra do polegar. Resultados: das 12 dimensões da cultura de segurança do paciente, nenhuma obteve escore acima de $75 \%$, sendo nove dimensões com escore entre $19 \%$ e $43 \%$ e três dimensões entre $55 \%$ e $57 \%$. Conclusões: não foram identificadas dimensões fortes para cultura de segurança nas três maternidades. Acredita-se que esses resultados possam contribuir na elaboração de políticas que promovam a cultura de segurança nas instituições.

Descritores: Segurança do Paciente; Cultura Organizacional; Unidade Hospitalar de Ginecologia e Obstetrícia; Estudos Transversais; Equipe de Assistência ao Paciente.

\section{RESUMEN}

Objetivos: evaluar la cultura de seguridad del paciente de la equipe de salud que actúa en tres maternidades. Métodos: estudio observacional, transversal, comparativo. Participaron del estudio 301 profesionales. Se ha utilizado el cuestionario Hospital Survey on Patient Safety Culture validado en Brasil. Para el análisis de los datos, ha sido considerado área fuerte en la cultura de seguridad del paciente cuando las respuestas positivas atingieron arriba de $75 \%$; y áreas que precisan de mejorías cuando las respuestas positivas atingieron menos de $50 \%$. Para la comparación de los resultados, se empleó desviación típica y regla del pulgar. Resultados: de las 12 dimensiones de la cultura de seguridad del paciente, ninguna obtuvo puntuación arriba de $75 \%$, siendo nueve dimensiones con puntuación entre $19 \%$ y $43 \%$ y tres dimensiones entre $55 \%$ y $57 \%$. Conclusiones: No han sido identificadas dimensiones fuertes para cultura de seguridad en las tres maternidades. Se cree que esos resultados puedan contribuir en la elaboración de políticas que promuevan la cultura de seguridad en las instituciones.

Descriptores: Seguridad del Paciente; Cultura Organizacional; Unidad Hospitalaria de Ginecología y Obstetricia; Estudios Transversales; Equipe de Asistencia al Paciente. 


\section{INTRODUCTION}

Patient safety is one of the pillars that support the quality of care worldwide and nationally. On the international stage, the World Alliance for Patient Safety proposes actions to address emerging patient safety problems ${ }^{(1-2)}$. At the national level, the Ministry of Health published Ordinance No. 529/2013, which instituted the National Patient Safety Program (NPSP) and the National Health Surveillance Agency (ANVISA) emitted the Resolution of the Collegiate Directorate (RCD) No. 36/2013. Both constitute regulatory frameworks that allow the incorporation of pro-security actions into the Brazilian health pragmatics and fosters debate on the theme ${ }^{(3-4)}$.

It is known that health professionals are inserted in a social and scientific practice. As participants in a social practice, they belong to the world of culture, possessing beliefs, worldviews and values that guide action. There are values that people have in them, and others belonging to an institution that aims to promote them in order to stimulate behaviors ${ }^{(5-6)}$.

In this sense, any policy to intervene in professional practice, in the promotion, prevention, treatment and rehabilitation of health, should be focused on moving the health professional to criticism and reflection on action, with the objective of rectifying or ratifying the values that underlie its pragmatics and, thereby, reduce morbidity and mortality in patients caused by adverse events (AE). The culture of patient safety is conceptualized as a set of behaviors, attitudes, perceptions, beliefs and values of professionals in a health organization. Therefore, it is necessary to analyze and understand the AEs, signaling to the health systems, the necessary change in the patient safety culture ${ }^{(6-7)}$.

Assessing the culture of patient safety in organizations has become a necessity, especially in the obstetric area, since data in the scientific literature is scarce. This assessment will make it possible to identify the existence of strong areas and areas with opportunities for improvement, reveal trends over time and define specific interventions that will impact patient safety. In a report by the Joint Commission (2004), perinatal death sentinel events and accidents during childbirth that revealed safety flaws were analyzed. The contributing factors of perinatal death were identified and classified; in 47 cases, $72 \%$ being related to communication; $55 \%$ to organizational culture; $47 \%$ to team competence, among others ${ }^{(8)}$.

It is recognized that the period that involves the pregnancy-puerperal cycle has a mix of expectation, consolidation of dreams, joys and, often, sadness in the family and health professionals. Undesirable situation perpetrated by the professional's action, due to malpractice, imprudence or negligence, among others, expose the mother-child binomial to health impacts.

It is known that technological advances cannot, in isolation, sustain the improvement of maternal and neonatal mortality indicators. Therefore, assessing the patient safety culture in obstetric care is of fundamental importance. In obstetric practice and, notably, in the maternity scenario, obtaining better results requires complex care changes that depend on the continuous efforts of the health team members ${ }^{(9)}$. Therefore, this study presents the following research question: How is the culture of patient safety of the health team working in three maternity hospitals?

\section{OBJECTIVES}

To assess the patient safety culture of the health team working in three maternity hospitals.

\section{METHODS}

\section{Ethical aspects}

The research complied with Resolution No. 466/2012 and was approved by the Ethics and Research Committee of the Federal University of Minas Gerais, under Opinion No. 2,027,964.

\section{Design, study location and period}

It is an observational, transversal, comparative study - (benchmarking), supported by the Strengthening the Reporting of Observational Studies in Epidemiology (STROBE) ${ }^{(10)}$. Benchmarking is a management tool with a systematic and continuous process of measuring and comparing the practices of an organization with others, in order to obtain information and opportunities that can help to improve the performance level of the practices ${ }^{(11)}$.

The study was carried out in three public maternity hospitals, with exclusive care for patients of the Unified Health System (UHS), located in the city of Belo Horizonte, Minas Gerais and all have a Patient Safety Center. The hospitals carry out teaching activities linked to health training. To preserve anonymity, the institutions received letters of the alphabet, namely: A, B and C.

Data was collected from November 2016 to June 2017.

\section{Sample, inclusion and exclusion criteria}

The selection of participants took place by convenience sampling. The inclusion criterion was to work at the unit for at least six months. The exclusion criteria were (1) nurses with legal leave from the service, (2) having answered the same questionnaire in another study institution, (3) instruments that presented more than $10 \%$ of lost data. Following all the criteria, 301 health professionals participated in the survey.

\section{Study protocol}

The data collection instrument used was the Hospital Survey on Patient Safety Culture (HSOPSC) questionnaire, validated in Brazil by Reis ${ }^{(12)}$, which has 42 items distributed in 12 dimensions of patient safety culture (Chart 1).

Chart 1 - Dimensions of the HSOPSC patient safety culture, Belo Horizonte, Minas Gerais, Brazil, 2017

\begin{tabular}{|l|}
\hline \multicolumn{1}{|c|}{ HSOPSC's patient safety culture dimensions } \\
\hline D1 - Teamwork within the units \\
\hline D2 - Supervisors' patient safety promotion expectations and actions \\
\hline D3 - Organizational learning \\
\hline D4 - Feedback and communication about error \\
\hline D5 - Communication opening \\
\hline D6 - Staff adequacy \\
\hline D7 - Non-punitive responses to mistakes \\
\hline
\end{tabular}

To be continued 
Chart 1 (concluded)

\begin{tabular}{|l|}
\hline \multicolumn{1}{|c|}{ HSOPSC's patient safety culture dimensions } \\
\hline D8 - Management support for patient safety \\
\hline D9 - Teamwork between units \\
\hline D10 - Duty shift or internal transfers \\
\hline D11 - General perceptions of patient safety \\
\hline D12 - Frequency of event notification \\
\hline Note: HSOPSC - Hospital Survey on Patient Safety Culture.
\end{tabular}

There were five categorical variables, namely: (a) direct care to the patient; (b) time at the institution; (c) time in the obstetric unit; (d) number of hours worked per week in the hospital; (e) position or function. These variables were analyzed using the absolute and relative frequencies.

\section{Analysis of results and statistics}

For the analysis of the data, the criterion found in the literature was used, of an area is considered strong in the patient safety culture, when the evaluated items obtain above $75 \%$ of positive responses (totally agree/agree), or those whose negative sentences reach $75 \%$ of the negative responses (strongly disagree/disagree) (7). The percentage established at $75 \%$ is arbitrary, and a higher or lower cut percentage can be chosen. The areas that need improvement are considered when the items evaluated obtain less than $50 \%$ positive responses. To calculate the percentages of positive responses to the dimensions, the number of positive responses to the items in the dimension was used, divided by the total number of valid responses (positive, neutral and negative) to the items in the dimension. The positive answers refer to the answers in which option 4 or 5 (totally agree/almost always/always agree) for positive questions, or 1 and 2 (strongly disagree/never or rarely) disagree for the questions asked in a negative way. The percentage established at $50 \%$ for areas that need improvement shows that, if half of the interviewees do not express positive opinions regarding a security problem, it is understood that there is room for improvement ${ }^{(7)}$.

To compare the results of the different dimensions of the patient safety culture, the methodology proposed by the Agency for Healthcare Research and Quality (AHRQ) was used, which recommends comparative analysis based on the percentage of positive responses, the standard deviation and the rule of thumb (thumb rule). In order to compare the positive percentage scores of hospitals, standard deviation was used, which is a measure of dispersion or variability of results around the mean. The result indicates how much the score differs from the general average. When using a difference of $5 \%$ indicated by the rule of thumb, when the standard deviation of the general average of hospitals is equal to or greater than $5 \%$, it is stated that there is a significant difference ${ }^{(13)}$.

\section{RESULTS}

301 professionals from the health team participated in the research, distributed as follows: 86 , from hospital $A ; 111$, from hospital $B$; and 104 , from hospital C. According to the characterization of professionals working in the three maternity hospitals, most reported having direct contact with the patient $(91.9 \%$, in hospital A; $95.5 \%$, in hospital B; and $97.1 \%$, in hospital C). Regarding the length of experience in the institutions, as well as in the work units most reported having up to ten years of professional experience. As for the workday: in hospitals $A$ and $B$, most professionals work up to 40 hours (64\% and $52.3 \%$ ); in hospital C, the workday exceeds 40 hours (68.3\%). \%). As for the item job / function, the predominant professional category in hospital A and B was the doctor (48.8\% and $47.8 \%$ ); and in hospital C, $64 \%$ of the professionals were nurses (Table 1).

The overall average score of the 12 dimensions of the patient safety culture was $40.7 \%$. The general average in the maternity hospitals, the standard deviation and the benchmarking result are shown below, based on the positive responses of the professionals who participated in the study (Table 2).

There were seven dimensions with a significant difference between the three maternities, respectively: "Teamwork within the units" , 48\%, 64\% and 60\% ( \pm 8); "Supervisor's expectations and actions" , 60\%, 67\% and 44\% ( \pm 12$)$; Feedback and communication about errors ", 30\%, 43\% and 38\% ( \pm 7); Openness to communication" , 41\%, 44\% and 33\% ( \pm 6$)$; "Internal transfers and duty shifts" , 38\%, $47 \%$ and $43 \%( \pm 5)$; "General perception of patient safety", 33\%, $41 \%$ and $30 \%( \pm 6) ;$;"Frequency of reported events", 30\%, 23\% and 39\% ( \pm 8$)$.

Table 1 - Work characteristics of the health team at the three maternity hospitals, Belo Horizonte, Minas Gerais, Brazil, 2017

\begin{tabular}{|c|c|c|c|c|c|c|c|c|c|}
\hline \multirow{2}{*}{\multicolumn{2}{|c|}{ Characterization of the health team }} & \multicolumn{2}{|c|}{ HA (N = 86) } & \multicolumn{2}{|c|}{$H B(N=111)$} & \multicolumn{2}{|c|}{$H C(N=104)$} & \multicolumn{2}{|c|}{ Total $(\mathrm{N}=301)$} \\
\hline & & $\mathbf{N}$ & $\%$ & $\mathbf{N}$ & $\%$ & $\mathbf{N}$ & $\%$ & $\mathbf{N}$ & $\%$ \\
\hline \multirow[t]{2}{*}{ Contact with the patient } & Yes & 79 & 91.9 & 106 & 95.5 & 101 & 97.1 & 286 & 95.0 \\
\hline & No & 07 & 8.1 & 05 & 4.5 & 03 & 2.9 & 15 & 5.0 \\
\hline \multirow[t]{3}{*}{ Time in institution (years) } & Up to 10 years & 60 & 69.8 & 110 & 99.0 & 85 & 81.7 & 255 & 84.7 \\
\hline & From 11 to 20 years & 16 & 18.6 & 01 & 1.0 & 18 & 17.3 & 35 & 11.6 \\
\hline & 21 or more & 10 & 11.6 & - & - & 01 & 1.0 & 11 & 3.7 \\
\hline \multirow[t]{3}{*}{ Time in obstetric unit (years) } & Up to 10 years & 62 & 72.1 & 107 & 96.4 & 83 & 79.8 & 252 & 83.7 \\
\hline & From 11 to 20 years & 16 & 18.6 & 04 & 3.6 & 18 & 17.3 & 38 & 12.6 \\
\hline & 21 or more & 08 & 9.3 & - & - & 03 & 2.9 & 11 & 3.6 \\
\hline \multirow[t]{2}{*}{ Working hours (week) } & Up to $40 \mathrm{~h}$ & 55 & 64.0 & 58 & 52.3 & 33 & 31.7 & 146 & 48.5 \\
\hline & More than $40 \mathrm{~h}$ & 31 & 36.0 & 53 & 47.7 & 71 & 68.3 & 155 & 51.5 \\
\hline \multirow[t]{4}{*}{ Office or function } & Nursing Assistant/Technician & 25 & 29.0 & 33 & 29.7 & 16 & 15.4 & 74 & 24.6 \\
\hline & Nurse & 08 & 9.4 & 13 & 11.7 & 67 & 64.4 & 88 & 29.2 \\
\hline & Doctor & 42 & 48.8 & 53 & 47.8 & 19 & 18.3 & 114 & 37.9 \\
\hline & Others & 11 & 12.8 & 12 & 9.9 & 02 & 2.0 & 25 & 8.3 \\
\hline
\end{tabular}


Table 2 - Evaluation of the dimensions of patient safety culture in the three maternity hospitals, Belo Horizonte, Minas Gerais, Brazil, 2017

\begin{tabular}{|c|c|c|c|c|c|c|c|c|c|}
\hline \multirow{2}{*}{ Dimension } & \multicolumn{2}{|c|}{ H1 } & \multicolumn{2}{|c|}{$\mathrm{H} 2$} & \multicolumn{2}{|c|}{ H3 } & \multicolumn{2}{|c|}{ Geral } & \multirow{2}{*}{$\begin{array}{l}\text { Diference } \\
\quad \geq 5 \%\end{array}$} \\
\hline & $\mu^{*}$ & $\sigma^{* *}$ & $\boldsymbol{\mu}^{*}$ & $\boldsymbol{\sigma}^{* *}$ & $\mu^{*}$ & $\boldsymbol{\sigma}^{* *}$ & $\mu^{*}$ & $\sigma^{* *}$ & \\
\hline Teamwork within the units & 48 & 11 & 64 & 15 & 60 & 14 & 57 & \pm 8 & Sim \\
\hline Supervisor's expectations and actions & 60 & 13 & 67 & 13 & 44 & 10 & 57 & \pm 12 & Sim \\
\hline Organizational learning / continuous improvement & 53 & 20 & 59 & 7 & 54 & 8 & 55 & \pm 3 & Não \\
\hline Error feedback and communication & 30 & 8 & 43 & 5 & 38 & 3 & 37 & \pm 7 & Sim \\
\hline Opening for communication & 41 & 17 & 44 & 12 & 33 & 16 & 39 & \pm 6 & Sim \\
\hline Staff & 41 & 20 & 43 & 17 & 37 & 23 & 40 & \pm 3 & Não \\
\hline Non-punitive response to error & 15 & 7 & 20 & 7 & 22 & 8 & 19 & \pm 4 & Não \\
\hline Hospital management support for patient safety & 43 & 7 & 40 & 5 & 41 & 2 & 41 & \pm 2 & Não \\
\hline Teamwork between units & 33 & 8 & 36 & 4 & 37 & 8 & 35 & \pm 2 & Não \\
\hline Internal transfers and on-call passes & 38 & 9 & 47 & 12 & 43 & 2 & 43 & \pm 5 & Sim \\
\hline General perception of patient safety & 33 & 20 & 41 & 14 & 30 & 13 & 35 & \pm 6 & Sim \\
\hline Frequency of reported events & 30 & 23 & 23 & 5 & 39 & 2 & 31 & \pm 8 & Sim \\
\hline
\end{tabular}

Note: * Percentage average of positive responses for items in this dimension; **Standard deviation.

\section{DISCUSSION}

The results of the study showed that the majority of professionals from the three maternity units reported having direct contact with the patient, which denotes the proximity and the intrinsic relationships that these workers maintain with the patients.

As for the time of professional practice at the institution and working in the area, most professionals were up to ten years old. It is recognized that the short time of work in a given area can compromise patient safety. However, if there is a recognition that the topic of "patient safety" is a fundamental value on the part of professionals, the theme can be addressed and the pragmatics will not suffer harmful influences on the levels of safety ${ }^{(14)}$.

Regarding the workday, in two maternities, was less than 40 hours a week, in the third was higher than this value. It is known that in the national scenario the workday is guaranteed by the Federal Constitution, maximum of eight hours per day and 44 hours per week. Alternative models can be made as long as filed by collective agreement such as a 12-hour working day for 36 hours of rest. Participants in safety culture research at a Malaysian general hospital reported a workload of more than 60 hours per week. Long and uninterrupted hours can negatively impact the patient's safe care by altering the professional's psychological and physical functioning ${ }^{(15-17)}$.

Regarding position or function, in hospital C, most participants are nurses. This result is attributed to the institutional policy of hospital C, as a model unit of the Stork Network for the training of human resources in obstetric nursing. In the area of Health, the nursing career constitutes half of the workforce and nurses have been appointed as the main responsible for coordinating teams at different levels of care ${ }^{(18)}$.

The general score of safety culture in the three maternities surveyed was $40.7 \%$. Of the 12 dimensions, nine are identified with a percentage of positive responses below $50 \%$. Although the researched institutions have their patient safety centers, the findings do not reflect the incorporation of the "patient safety" value with the respondents. These results are inferior to those found in other studies, such as the one performed in a general hospital in Malaysia ${ }^{(17)},(50.1 \%)$ and in the AHRQ teaching hospital database, whose overall safety culture average was $63 \%{ }^{(12)}$. Considering that, among the results found in this study, more than half of the answers were negative for the safety culture, it is assumed that there is a need for improvements.

The dimension "expectations and actions of the supervisor" obtained the greatest significant difference $( \pm 12)$, considered the most worrying according to the responses of the professionals of the three maternities. In hospital C, the dimension that presented the lowest percentage of positive responses was (44\%), much lower than data found in other studies, in which hospitals presented $65 \%$ and $67 \%$ of positive responses ${ }^{(19-20)}$, as well as the teaching hospitals of AHRQ which presented $77 \%{ }^{(13)}$. In this dimension, the professionals consider that chief supervisors are not concerned with issues related to patient safety, which reveals a critical situation for hospital administration.

The promotion of a safety culture must be the responsibility and priority of everyone, especially professionals who occupy positions in the institutional hierarchy. They set the goals and plan policies that aim to promote the value of patient safety. On the other hand, supervisors conduct day-to-day work processes. If managers are not committed to promoting a patient safety culture, it is unlikely that health team members will feel committed and responsible for patient safety ${ }^{(21)}$. On the other hand, the authors of a study carried out in Finland identified that hospital managers seriously consider actions that can improve patient safety ${ }^{(20)}$.

Regarding the dimension "Teamwork within the units", there was a significant difference between the professionals of the three maternities $( \pm 8)$. The percentage of positive responses was better for hospitals B (64\%) and C (60\%) when compared to hospital A (48\%). These results reveal that there is little cooperation for working together, especially among professionals from hospital A. A similar result was found in a study carried out in two hospitals, one in Brazil and the other in Portugal(22). Therefore, in order to build co-responsibility of those involved in patient safety, individual and parceled work for the articulated and integrated must be substituted ${ }^{(23)}$. The results of teaching hospitals revealed in the AHRQ report are far superior to those mentioned above, in which $80 \%$ reveal a strong safety culture for this dimension ${ }^{(13)}$.

"Frequency of reported events" was another dimension that showed a significant difference $( \pm 8)$, among professionals from the three maternity hospitals with percentages of $30 \%$ in hospital A; 23\%, hospital B; and 39\%, hospital C. It is observed 
that in the three institutions the percentage error notification is low. This may be happening due to the lack of instruments for reporting adverse events and by the culture of institutional "silence". It is noteworthy that nurses from hospital B reported errors less frequently. The literature points out that the team's lack of knowledge or lack of understanding that any professional is subject to error can trigger feelings of shame, guilt and fear for this person, which can be aggravated by the punitive culture, prevalent in the institutions under study and contribute to the omission of failures ${ }^{(24)}$.

Another dimension that revealed a significant difference between professionals was "Feedback and communication about errors" ( \pm 8$)$, whose percentage of positive responses was $30 \%$ for hospital A, $43 \%$ and $38 \%$ for hospitals B and C, respectively. This result, similar to that found in the scientific literature ${ }^{(22)}$ shows that the different professionals working in these units have little feedback on the process of handling reported errors.

One way to identify the factors that influence the occurrence of adverse events is through their analysis. More in-depth knowledge about events at the unit can help to improve the quality of care provided ${ }^{(25-26)}$. An intervention study evaluated the safety culture before and after the educational intervention and reached important results, since reporting errors helped in identifying opportunities for improvement, in understanding risk situations and in learning to prevent similar occurrences ${ }^{(20)}$.

The dimension "Opening for communication" revealed a significant difference between the professionals of the three maternity hospitals $( \pm 6)$, with percentages of positive responses ranging from $33 \%$ to $44 \%$. In this dimension, the professionals of the institutions realized that there is little freedom to report situations that can affect patient safety. Superior results were found in the study by Tomazoni ${ }^{(27)}$, in which nurses and doctors obtained $55 \%$ positive responses for this dimension. In AHRQ teaching hospitals, the score for this dimension was $62 \%{ }^{(13)}$. The communication process deserves extra attention by the leaders of hospital organizations. Currently, open and transparent communication becomes a challenge for leaders in their daily lives; however, it must be incorporated as an indispensable element in conducting the work ${ }^{(28)}$.

Significant difference between the professionals of the three maternity hospitals was also observed in the dimension "General perception of patient safety" $( \pm 6)$, whose percentages of positive responses ranged from $30 \%$ to $41 \%$. A study carried out in a psychiatric hospital found similar results, $(42 \%)^{(20)}$, but AHRQ teaching hospitals reported a general perception of patient safety above those values, $63 \%{ }^{(13)}$. According to these results, professionals recognize that the systems are not efficient to prevent errors. Factors such as fatigue, overwork, insufficient staff, unsafe procedures and systems can compromise patient safety ${ }^{(29)}$.

The dimension "Internal transfers and duty shifts" presented a significant difference between professionals $( \pm 5)$, whose percentages of positive responses were less than $50 \%$ in the three institutions. These results confirm the communication problems already evidenced in this study. Similar results were found by Jye et al (2019)(17), the authors justified the low score due to the complexity of tertiary care and the consequent increase in workload. Among AHRQ American teaching hospitals, the score for this dimension was $45 \%{ }^{(13)}$. Data from a study carried out in a Finnish psychiatric hospital report an even lower score for this dimension of $35 \%{ }^{(20)}$.

Information during internal transfers and shift changes are one of the main ways to promote continuity of patient care. If there is a failure, the flows may be compromised and the continuity of care exposed to errors with the patient. This consideration confirms the scientific literature when reporting the experience of a hospital in the southern region of Brazil, whose results show that important information about patient care is often lost during shift changes. Still, the referred study highlights that the problems of this type do not happen only between the teams of different sectors, but also, between those of the same unit ${ }^{(26)}$.

The culture of safety in midwifery is emerging and should encourage health professionals to adopt a proactive approach to prevent failures in the care process. It is suggested to use the results of the present study to create educational strategies aimed at the gradual change in the safety culture among health professionals.

\section{Study limitations}

The study's selection process is considered a limitation of convenience, which can certainly impact the representativeness of professionals from participating institutions. Another limitation is the scarcity of studies that evaluate safety culture in the area of obstetrics, a fact that made it difficult to compare data.

\section{Contributions to the area}

The results of this study reveal the areas that need improvement in the patient safety culture at the three institutions. Therefore, such information may serve for managers to develop intervention plans to improve these areas and, consequently, obtain better care results. In addition, evaluating the safety culture allows the development of future research that measures the impact of the implemented measures.

\section{CONCLUSIONS}

When evaluating the safety culture, it is stated that no strong dimensions for the patient safety culture were identified in the three maternity hospitals. Several factors may be acting synergistically to maintain this situation on the part of the professionals who work in the maternity hospitals participating in the study, highlighting: poor communication between the shifts; the errors little used to promote a safety culture among professionals; the underreporting of adverse events; ; the difficulty for team work; managers and supervisors with reduced aptitude and acceptance of the "patient safety" theme; and the perception of professionals that measures for patient safety are not valued by the institution. It is believed that the study can provide elements for the reflection of health professionals and assist them in the elaboration of policies that promote in the institutional culture, of which they are subject, the insertion of the "patient safety" value, allowing their pragmatic care to be successful and safe. 


\section{REFERENCES}

1. Souza P, Mendes W. Segurança do paciente: conhecendo os riscos nas organizações de saúde. Rio de Janeiro: FIOCRUZ; 2014. 2v.

2. Donaldson L, Philip P, World Health Organization (WHO). Patient safety: a global priority. Bull World Health Organ [Internet]. 2004 [cited 2018 Feb 20]. Available from: https://www.who.int/bulletin/volumes/82/12/editorial11204html/en/

3. Brasil. Ministério da Saúde. Portaria n 529 de $1^{\circ}$ de abril de 2013. Institui o Programa Nacional de Segurança do Paciente (PNSP). Brasília; 2013 [cited 2018 Feb 20]. Available from: http://bvsms.saude.gov.br/bvs/saudelegis/gm/2013/prt0529_01_04_2013.html

4. Agência Nacional de Vigilância Sanitária. Resolução RDC n 36 de 25 de julho de 2013. Institui ações para a segurança do paciente em serviços de saúde e dá outras providências. Brasília; 2013 [citado 2018 Feb 20]. Available from: http://portal.anvisa.gov.br/ documents/10181/2871504/RDC_36_2013_COMP.pdf/36d809a4-e5ed-4835-a375-3b3e93d74d5e

5. Amalberti R, Rocha R, Vilela RAG, Almeida IM. Safety management in complex and dangerous systems: theories and practices: an interview with Rene Amalberti. Rev Bras Saude Ocup [Internet]. 2018 [cited 2018 Mar 15];43:e9. doi: 10.1590/2317-6369000021118

6. Guimarães GL, Chianca TCM, Mendoza IYQ, Goveia VR, Matos SS, Viana LO. The core values of modern nursing in the light of Dilthey and Scheler. Texto Contexto Enferm. 2015;24(3):898-905. doi: 10.1590/0104-07072015003480014

7. Sorra J, Nieva VF. Hospital Survey on Patient Safety Culture. (Prepared by Westat, under Contract No. 290-96-0004). AHRQ Publication No. 04-0041. Rockville, MD: Agency for Healthcare Research and Quality [Internet]. 2004 [cited 2019 Apr 16]. Available from: https://proqualis.net/sites/proqualis.net/files/User\%20 guide\%2OHSOPSC.pdf

8. Joint Commission. Preventing infant death and injury during delivery. The Joint Commission Sentinel Event Alert [Internet]. 2004 [cited 2019 Oct 28];30. Available from: https://www.jointcommission.org/assets/1/18/SEA_30.PDF

9. Ruoff AB, Andrade SR, Schmitt MD. Activities developed by the committees of prevention of infant and fetal deaths: integrative review. Rev Gaúcha Enferm [Internet]. 2017 [cited 2019 Apr 15];38(1):e67342. doi: 10.1590/1983-1447.2017.01.67342

10. Von Elm E, Altman DG, Egger M, Pocock SJ, Gotzsche PC, Vandenbroucke JP. The Strengthening the Reporting of Observational Studies in Epidemiology (STROBE) Statement: guidelines for reporting observational studies. Bull World Health Organ [Internet]. 2007 [cited 2019 Jan 18];85(11):867-72. Available from: https://www.ncbi.nlm.nih.gov/pmc/articles/PMC2636253/pdf/07-045120.pdf

11. Anand G, Kodali R. Benchmarking the benchmarking models. Benchmarking An Int J [Internet]. 2008 [cited 2019 Apr 20];15(3):257-91. Available from: https://www.emeraldinsight.com/doi/pdfplus/10.1108/14635770810876593

12. Reis CT, Laguardia J, Vasconcelos AGG, Martins M. Reability and validity of the Brazilian version of the Hospital Survey on Patient Safety Culture (HSOPSC): a pilot study. Cad Saúde Pública [Internet]. 2016 [cited 2019 Mar 10]; 32(11):e00115614. doi: 10.1590/0102-311x00115614

13. Famolaro T, Yount ND, Burns W, Flashner E, Liu H, Sorra J. Hospital Survey on Patient Safety Culture: 2016 Comparative Database Report. Agency for Healthcare Research and Quality; March 2016. Available from: https://www.ahrq.gov/sites/default/files/wysiwyg/professionals/ quality-patient-safety/patientsafetyculture/hospital/2016/2016_hospitalsops_report_pt2-3.pdf

14. Reis CT, Martins M, Laguardia J. A segurança do paciente como dimensão da qualidade do cuidado de saúde: um olhar sobre a literatura. Ciênc Saúde Colet [Internet]. 2013 [cited 2019 Apr 15];18(7):2029-36. Available from: http://www.scielo.br/pdf/csc/v18n7/18.pdf

15. Brasil. Constituição da República Federativa do Brasil: texto constitucional promulgado em 5 de outubro de 1988 , com as alterações determinadas pelas Emendas Constitucionais de Revisao n ${ }^{\circ} 1$ a 6/94, pelas Emendas Constitucionais n $1 / 92$ a 91/2016 e pelo Decreto Legislativo no 186/2008. Brasília: Senado federal, Coordenação de Edições Técnicas, 2016. Available from: https://www2.senado.leg.br/bdsf/ bitstream/handle/id/518231/CF88_Livro_EC91_2016.pdf

16. Câmara dos Deputados (BR). Decreto Lei № 5.452, de $1^{\circ}$ de maio de 1943. Aprova a Consolidação das Leis do Trabalho [Internet]. Brasília; 1943 [citado 2019 May 5]. Available from: https://www.camara.leg.br/sileg/integras/572513.pdf

17. Jye AKR, Hing CZ, Peter S, Bartholomew P. Hospital survey on patient safety culture in Sarawak General Hospital: a cross sectional study. Med J Malaysia [Internet]. 2019 [cited 2019 Nov 4];74(5):385-8. Available from: http://www.e-mjm.org/2019/v74n5/patient-safety-culture.pdf

18. Cassiani SHB, Lira Neto JCG. Nursing Perspectives and the "Nursing Now" Campaign. Rev Bras Enferm. 2018;71(5):2351-2. doi: 10.1590/0034-7167.2018710501

19. Macedo TR, Rocha PK, Tomazoni A, Souza S, Anders JC, Davis K. The culture of patient safety from the perspective of the pediatric emergency nursing team. Rev Esc Enferm USP [Internet]. 2016 [cited 2019 Apr 15];50(5):756-762. doi: 10.1590/s0080-623420160000600007

20. Kuosmanen A, Tiihonen J, Repo-Tiihonen E, Eronen M, Turunen H. Changes in patient safety culture: a patient safety intervention for Finnish forensic psychiatric hospital staff. J Nurs Manag [Internet]. 2019[cited 2019 Nov 4];27:848-57. Available from: https://onlinelibrary.wiley.com/ doi/epdf/10.1111/jonm.12760

21. Rocha IARS, Santos MR, Pires RMF. Supervisão à distância em enfermagem: uma realidade desejada pelos enfermeiros. Referência [Internet]. 2016 [cited 2019 Apr 15];IV(10):95-102. doi: 10.12707/RIV16025

22. Fassarela CS, Camerini FG, Henrique DM, Almeida LF, Figueiredo MCB. Evaluation of patient safety culture: comparative study in university hospitals. Rev Esc Enferm USP [Internet]. 2018 [cited 2019 Apr 15];52:e03379. doi: 10.1590/s1980-220x2017033803379 
23. Souza KV, Santos Filho SBS, Carmo JMA, Vallerini APLG. Caderno do Curso de Aprimoramento em Enfermagem Obstétrica: qualificação para o trabalho em equipe no cuidado ao parto e nascimento[Internet]. Belo Horizonte: Escola de Enfermagem da UFMG; 2019 [cited 2019 Apr 15]. Available from: http://portaldeboaspraticas.iff.fiocruz.br/apice/wp-content/uploads/2019/04/caderno_Curso_Aprimoramento_ Enfermeiras_Obst\%C3\%A9tricas.pdf

24. Duarte SCM, Stipp MAC, Silva MM, Oliveira FT. Adverse events and safety in nursing care. Rev Bras Enferm [Internet]. 2015 [cited 2019 Apr 15];68(1):136-46. Available from: http://www.scielo.br/pdf/reben/v68n1/en_0034-7167-reben-68-01-0144.pdf

25. Hoffmeister LV, Moura GMSS, Macedo APMC. Learning from mistakes: analyzing incidents in a neonatal care unit. Rev Latino-Am Enfermagem [Internet]. 2019 [cited 2019 Apr 15];27:e3121. doi: 10.1590/1518-8345.2795.3121

26. Bohrer CD, Marques LGS, Vasconcelos RO, Oliveira JLC, Nicola AL, Kawamoto AM. Comunicação e cultura de segurança do paciente no ambiente hospitalar: visão da equipe multiprofissional. Rev Enferm UFSM [Internet]. 2016 [cited 2019 Apr 15];6(1):50-60. Available from: https://periodicos.ufsm.br/reufsm/article/view/19260/pdf_1

27. Tomazoni A, Rocha PK, Kusahara DM, Souza AIJ, Macedo TR. Evaluation of the patient safety culture in neonatal intensive care. Texto Contexto Enferm [Internet]. 2015 [cited 2019 Apr 15];24(1):161-9. doi: 10.1590/0104-07072015000490014

28. Vasconcelos RMA, Caldana G, Lima EC, Silva LDM, Bernardes A, Gabriel CS. Communication in the relationship between leaders and lead in the context of nursing. Rev Enferm UFPE. 2017 [cited 2019 Apr 15];11(Supl.11):4767-77. Available from: https://periodicos.ufpe.br/revistas/ revistaenfermagem/article/viewFile/231220/25236

29. Hershey K. Culture of safety. Nurs Clin N Am [Internet]. 2015 [cited 2019 Apr 15];50:139-52. doi: 10.1016/j.cnur.2014.10.011 